\title{
СИНТЕЗ АЛКЕНИЛСУЛЬФОНАТОВ НА ОСНОВЕ ПРОДУКТОВ ТЕЛОМЕРИЗАЦИИ ПИПЕРИЛЕНА
}

В литературе описаны известные способы получения алкилсульфонатов путем конденсации галоидалкила с сульфитом натрия ['].

Алкилсульфонаты с радикалом, который содержит в цепи более 12 атомов углерода, являются анионактивными поверхностно-активными веществами (ПАВ). Исходным сырьем для синтеза таких ПАВ могут служить также высшие галоидные алкилы типа аллила, т. е. соединения, у которых атом хлора находится в $\alpha$-положении по отношению к двойной связи. Они легче вступают в реакцию обмена с сульфитом натрия, чем соответствующие насыщенные соединения. Однако получение таких ненасыщенных галоидалкилов связано с высокотемпературным хлорированием 1-алкенов [ $\left.{ }^{2}\right]$.

В литературе описаны также способы синтеза алкенилсульфокислот действием на 1-алкены сульфирующим газом, содержащим около $5 \%$ об. свободной трехокиси серы $\left.{ }^{3-6}\right]$. Получаемые олефинсульфокислоты проявляют хорошие поверхностно-активные свойства в жесткой воде. Однако выход продукта является небольшим. Производство алкенилсульфонатов сдерживается дефицитом и дороговизной 1-алкенов.

В целях расширения круга источников сырья для получения ПАВ типа алкенилсульфонатов мы использовали пиперилен-диеновый углеводород, содержащий пять атомов углерода в молекуле. Әто соединение в значительных количествах образуется вместе с изопреном, синтезируемым в нашей стране в промышленных масштабах для получения синтетического каучука путем дегидрирования пентан-пентеновых нефтяных фракций. Изопрен выделяется из реакционной смеси, а пиперилен в виде более тяжелых кубовых остатков в основном используется в качестве разбавителя топочного мазута.

Наращивание углеводородной цепи осуществляли путем теломеризации пиперилена с его гидрохлоридом, получаемым путем гидрохлорирования пиперилена сухим газообразным хлористым водородом, в присутствии катализатора - (IV) хлорида олова:

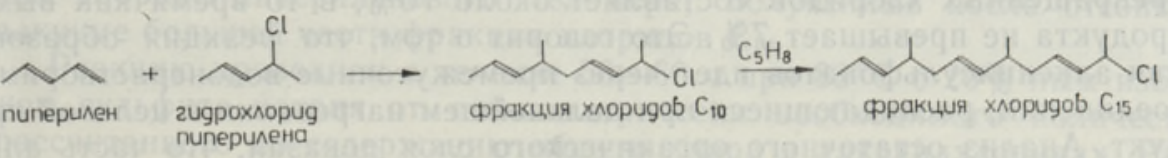

Таким образом получали алкенилхлориды $\mathrm{C}_{10}, \mathrm{C}_{15}$ и некоторое количество $\mathrm{C}_{20}$. В таких соединениях атом хлора находится в $\alpha$-положении по отношению к двойной связи. Алкенилхлориды $\mathrm{C}_{15}$ служат исходным сырьем для синтеза сульфонатов.

Получаемая в результате реакции теломеризации фракция хлоридов $\mathrm{C}_{10}$ малопригодна для синтеза сульфонатов. Утилизация ее, после выделения отгонкой из реакционной смеси, возможна путем проведения повторной теломеризации с пипериленом или дивинилом. При этом вакуумная отгонка фракции хлоридов $\mathrm{C}_{10}$ ведется не до конца, так как 
алкенилхлориды при дистилляции дают азеотроп и, кроме того, исчерпывающее удаление хлоридов $\mathrm{C}_{10}$ сопряжено с потерями ценной фракции хлоридов $\mathrm{C}_{15}$. В связи с этим исходное сырье для синтеза сульфонатов, помимо более высокомолекулярных алкенилхлоридов, содержит до $10 \%$ фракции хлоридов $\mathrm{C}_{10}$.

При проведении реакции алкенилхлоридов с сульфитом натрия в спирто-водной среде в найденных оптимальных условиях выход сульфонатов составил порядка $48-52 \%$ мас. при конверсии исходного алкенилхлорида порядка $70 \%$. На выход сульфонатов, при прочих равных условиях проведения реакции, влияет соотношение алкенилхлоридов и спирто-водного раствора. Здесь оптимальным является соотношение $1: 10$.

При снижении избытка спирто-водного раствора по отношению к исходным алкенилхлоридам до трех выход сульфонатов не превышает $33 \%$, а при пятикратном избытке он равен $36,7 \%$. Было также установлено, что концентрация спирто-водного раствора практически не влияет на выход продукта. Поэтому все дальнейшие опыты по получению алкенилсульфонатов проводили в 10\%-ном спирто-водном растворе. Такая концентрация спирта необходима для ингибирования реакции окисления сульфита натрия в ходе процесса. При продолжительности реакции 60 ч выход алкенилсульфонатов является наибольшим и составляет $50-52 \%$. При меньшей продолжительности наблюдается снижение выхода продукта. Так, после 5 ч выход составляет $6,8 \%$, после 20 ч $25,1 \%$, после 30 ч $-34,2 \%$.

В условиях проведения реакции представляла интерес динамика превращения алкенилхлоридов в сульфонаты. Поэтому через определенные промежутки определяли содержание хлора в исходном сырье, а также выход алкенилсульфонатов (табл. 1).

Таблица 1

Динамика превращения алкенилхлоридов в сульфонаты

\begin{tabular}{|c|c|c|c|c|c|c|c|}
\hline \multirow{2}{*}{ Показатель } & \multicolumn{7}{|c|}{ Время реакции, ч } \\
\hline & 1 & 5 & 10 & 15 & 20 & 30 & 60 \\
\hline $\begin{array}{l}\text { Количество превращенных } \\
\text { исходных хлоридов, \% мас. }\end{array}$ & 48,6 & 68,2 & 69,6 & 70,5 & 71,1 & 72,0 & 73,2 \\
\hline $\begin{array}{l}\text { Выход алкенилсульфона- } \\
\text { тов, \% мас. }\end{array}$ & 1,7 & 6,8 & 12,5 & 19,3 & 25,1 & 34,2 & 51,8 \\
\hline
\end{tabular}

Қак видно из табл. 1, уже в течение первых пяти часов количество превращенных хлоридов составляет около $70 \%$, в то время как выход продукта не превышает $7 \%$. Это говорит о том, что реакция образования алкенилсульфонатов идет через промежуточные водонерастворимые соединения, распадающиеся при дальнейшем нагревании в целевой продукт. Анализ остаточного органического слоя показал, что часть алкенилхлоридов гидролизуется с образованием спиртов (см. табл. 3) и часть, возможно, дегидрохлорируется. В дальнейшем представляет интерес установить химическую природу образующегося промежуточного соединения, а также механизм его превращения.

Раствор алкенилсульфонатов после отделения от органического слоя промывали бензином и упаривали в вакууме. Остаток экстрагировали этанолом и сушили при $30-40{ }^{\circ} \mathrm{C}$.

Статическое поверхностное натяжение водных растворов различной концентрации определяли сталагмометрическим методом при $20^{\circ} \mathrm{C}$ (табл. 2). 
Характеристика поверхностной активности алкенилсульфонатов с различной средней эквивалентной массой

\begin{tabular}{|c|c|c|c|c|}
\hline \multirow[t]{2}{*}{ Образец } & \multicolumn{4}{|c|}{$\begin{array}{c}\text { Поверхностное натяжение, } 10-5 \mathrm{H} / \mathrm{cm} \text {, } \\
\text { водных растворов ПАВ, \% мас. }\end{array}$} \\
\hline & 0,5 & 0,25 & 0,125 & 0,063 \\
\hline Додецилсульфат натрия (эталон) & 39,2 & 39,3 & 41,3 & 52,8 \\
\hline $\begin{array}{r}\text { Алкенилсульфонат } \\
\text { эКв. масса } 293 \\
\text { экв. масса } 324\end{array}$ & $\begin{array}{l}33,4 \\
31,3\end{array}$ & $\begin{array}{l}37,0 \\
32,1\end{array}$ & $\begin{array}{l}44,8 \\
33,8\end{array}$ & $\begin{array}{l}51,5 \\
39,4\end{array}$ \\
\hline
\end{tabular}

Как видно из табл. 2, хорошими показателями по снижению поверхностного натяжения обладает сульфонат с эквивалентной массой 324 (среднее число атомов углерода 15), в то время как продукт с эквивалентной массой 293 (среднее число атомов углерода 13) близок по своим свойствам эталону (12 атомов углерода в алкильной цепи).

Как правило, углеводородный радикал сульфоната имеет несколько меньшее среднее число атомов углерода, чем этого следует ожидать исходя из средней молекулярной массы исходного алкенилхлорида. По-видимому, это связано с реакционной способностью хлоридов, которая убывает с увеличением их молекулярной массы. Такое предположение подтверждается также и тем, что после реакции величина средней молекулярной массы остаточного сырья выше, чем у исходных хлоридов (табл. 3).

Биохимическое окисление алкенилсульфонатов оценивалось стандартным методом инкубационных флаконов Воронежским филиалом ВНИИ синтетического каучука. Степень биохимического окисления составила $80 \%$. Такой результат соответствует современным требованиям, предъявляемым к синтетическим ПАВ.

Алкенилсульфонаты хорошо зарекомендовали себя в качестве эмульгаторов для приготовления препаративной формы аналогов ювенильного гормона. Последние являются безвредными для окружающей среды химическими средствами защиты от сельскохозяйственных вредителей (тепличной белокрылки, листовой тли, паутинного клеща, мучного хрущака и др.).

\section{Экспериментальная часть}

Исходным сырьем для алкенилсульфонатов служили соответствующие хлориды пипериленового теломера, полученные после отгонки в вакууме большей части фракции хлоридов $\mathrm{C}_{10}$.

Реакцию проводили в течение $50-60$ ч при $80^{\circ} \mathrm{C}$ с $20 \%$-ным избытком сульфита натрия от стехиометрически необходимого количества, рассчитанного по содержанию общего хлора в алкенилхлоридах. Растворителем служил $10 \%$-ный водный раствор 2-пропанола, взятый по массе в отношении к сырью $10: 1$. В реактор, снабженный мешалкой, термометром и обратным холодильником, вливали воду и, перемешивая, последовательно загружали сульфит натрия, 2-пропанол и алкенилхлориды. По окончании реакции остаточное сырье отделяли от спирто-водного раствора продукта путем экстракции петролейным эфиром с $t_{\text {кип }}$ $70-100^{\circ} \mathrm{C}$, а из раствора алкенилсульфонатов при помощи вакуумной перегонки отгоняли спирто-водный азеотроп и воду до начала интенсивного пенообразования, после чего концентрат упаривали на водяной бане. В целях извлечения продукта сухой остаток обрабатывали этано- 
лом. Спиртовой раствор продукта отделяли от выпадающих минеральных солей, этанол отгоняли. Густой остаток продукта высушивали до постоянной массы. Выход алкенилсульфонатов составлял порядка $50 \%$. Остаточное сырье в петролейном эфире высушивали над хлористым кальцием (сульфатом магния), после чего петролейный эфир отгоняли.

А. Брали 160,0 г исходных алкенилхлоридов, 84,5 г сульфита натрия, $1600 \mathrm{r}$ водного 2-пропанола (10\%-ной концентрации). Получали 82,0 г алкенилсульфонатов со средней эквивалентной массой 324 (выход 51,3\% от исходной фракции) и 83,2 г остаточного сырья.

Б. Брали 72,0 г исходных алкенилхлоридов, 38,0 г сульфита натрия, 720 г водного 2 -пропанола (10\%-ной концентрации). Получали 38,0 г алкенилсульфонатов со средней эквивалентной массой 293 (выход $52,8 \%$ от исходной фракции) и 36,7 г остаточного сырья.

Характеристика исходного и остаточного сырья приведена в табл. 3.

Таблица 3

Характеристика исходных алкенилхлоридов и остаточного сырья после реакции

\begin{tabular}{l|c|c|c|c}
\hline \multirow{2}{*}{ Показатель } & \multicolumn{1}{|c|}{$\begin{array}{c}\text { Исходные алкенил- } \\
\text { хлорнды }\end{array}$} & Остаточное сырье \\
\cline { 2 - 4 } & А & Б & А & Б \\
\hline
\end{tabular}

Содержание, \% мас.

фракция хлоридов $\mathrm{C}_{10}$ $\mathrm{C}_{20}$ и выше

суммарный хлор

гидроксильная группа

расчетное к-во спиртов

Молекулярная масса

Плотность $d_{4}^{20}$

Показатель преломления $n_{D}^{20}$

10,0
24,0
66,0
12,4
-

269

0,9102

1,4848

\section{5,0}

29,6

13,8

二

242

0,8991

1,4751

$\begin{array}{ll}- & - \\ \overline{3} & - \\ 1,75 & 3,90 \\ 29,0 & 1,71 \\ 26,0\end{array}$

282

261

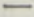

1,4777

Данные лабораторных исследований по параметрам процесса получения алкенилсульфонатов проверяли и дополняли на установке Опытного завода органического синтеза и биопрепаратов Института химии АН ЭССР. Были сняты матернальные балансы процесса и установлены энергетические затраты. Расход сырья на 1 кг технического продукта составил, \% мас.: алкенилхлориды $\mathrm{C}_{15}$ и выше 1,38 , сульфит натрия $0,81,2$-пропанол 0,13 , экстракционный бензин 0,14 .

Полученный технический продукт содержал более $92 \%$ активного вещества, $1,5 \%$ минеральных солей и не являлся токсичным соединением, его ЛД 50 - более 2000 мг/кг.

\section{Выводы}

1. Разработан способ получения поверхностно-активных веществ алкенилсульфонатов на основе продуктов теломеризации пиперилена.

2. Реакция осуществлена между алкенилхлоридами и сульфитом натрия в среде $10 \%$-ного водного 2-пропанола в течение $50-60$ ч при температуре $80{ }^{\circ} \mathrm{C}$. Выход продукта составляет в среднем $50 \%$.

3. Помимо целевого продукта, в результате гидролиза хлоридов образуются высшие спирты, количество которых в отработанном сырье достигает $25-30 \%$. 
4. Синтезированный алкенилсульфонат со средним числом углеродных атомов в молекуле $\mathrm{C}_{15}$ обладает хорошими поверхностно-активными свойствами.

5. Степень биологического окисления нового продукта (не менее $80 \%$ ) удовлетворяет существующим требованиям к поверхностно-активным веществам. Он не является токсичным соединением, его ЛД составляет более $2000 \mathrm{мr} / \mathrm{кг}$.

6. На Опытном заводе органического синтеза и биопрепаратов Института химии АН ЭССР проведена укрупненная проверка способа получения алкенилсульфонатов, сняты материальные балансы и определены энергетические затраты производства.

7. Полученный технический продукт с содержанием активного вещества алкенилсульфонатов более $92 \%$ зарекомендовал себя хорошим эмульгатором в составе препаративной формы аналогов ювенильного гормона - новых безвредных для окружающей среды химических средств борьбы с вредными насекомыми, причиняющими ущерб сельскому хозяйству.

\section{Л И ТЕ Р А Т У Р А}

1. Zuffanti, S. Die Darstellung einiger aliphatischer Sulfonsäuren mit verzweigter Kette. - Chem. Zbl., 1940, 11, N 17, 2292-2296.

2. Шварц А., Перри Дж. Поверхностно-активные вещества. М., 1953, 86.

3. Hänssle, S.P.F., Kosswich, K., Maat, H. Wytwarzanic i wlasności uzytkowe alkenylsulfonianów. - Pollena, 1975, 19, N 7-8, 324-348.

4. Tuvell, M. E., Kuehnhanss, G. O., Heidelbrecht, G. D., Hu, P. C., Zielinski, A. D. AOS - an anionic surfactant system; its manufacture composition, properties and potential application. - J. Amer. Oil Chem. Soc., 1978, 55, N 1, 70-80.

5. Мельник А. П., Гаевой Г. М., Правдин В. Г., Подустов М. А. Получение анионных

ПАВ. - Нефтеперераб. и нефтехим., 1979, № 8, 38-40.

6. Щукин Е. Д., Гершенович А. И. Поверхностно-активные вещества - состояние и перспективы развития производств. - Ж. Всес. хим. о-ва им. Д. И. Менделеева, 1980, 25, № 5, 573-581.
Институт химии
Академии наук Эстонской ССР Поступила в редакцию
$1 /$ XII 1986

Tatjana LIIV, I. KUDRJAVTSEV, A. KOGERMAN, K. LAATS

\section{ALKENUULSULFONAATIDE SUNTEES PIPERULEENI TELOMERISATSIOONI PRODUKTIDE BAASIL}

Artiklis on kirjeldatud meetodit pindaktiivsete ainete - alkenüülsulfonaatide saamiseks keskmise süsinikuaatomite arvuga $\mathrm{C}_{15}$ piperüleeni telomerisatsiooni produktide baasil. Reaktsioon on teostatud naatriumsulfitiga $80^{\circ} \mathrm{C}$ juures $10 \%$-lise isopropanooli lahuses. Produkti saagis on ligikaudu $50 \%$ lähteainest. Saadud alkenüülsulfonaat on heade pindaktiivsete omadustega ja allub kergesti bioloogilisele oksüdatsioonile.

\section{Tatyana LIIV, I. KUDRYAVTSEV, A. KOGERMAN, K. LAATS}

\section{SYNTHESIS OF ALKENYL SULFONATES ON THE BASIS OF TELOMERIZATION PRODUCTS OF PIPERYLENE}

The authors describe a method of obtaining surface-active surfactants - alkenyl sulfonates with 15 carbon atoms in the molecule on the basis of the telomerization products of piperylene. The reaction is carried out with sodium sulphite at $80^{\circ} \mathrm{C}$ in $10 \%$ aqueous isopropanol solution. The product yield makes about $50 \%$ of the initial material. The alkenyl sulfonate obtained has good surface-active properties and it is easily biooxidizable. 